\title{
An Analysis of Students' Anxiety in Speaking
}

\author{
Uli Modesta Siagian ${ }^{1}$, Adam $^{2}$ \\ English Education Department \\ University of RiauKepulauan \\ ulimodestasiagian@yahoo.co.id ${ }^{l}$, ayamezhu@yahoo.com ${ }^{2}$
}

\begin{abstract}
This thesis aims to define the factors of students' speaking anxiety and how the students' strategies to overcome speaking anxiety in the class room. The problem in this research is anxiety of tenth grade students SMK Indomalay School Batam to speak in classroom. Based on the issues above, the purpose of this researcher is to define the factor causing of speaking anxiety and how the students' strategies to overcome speaking anxiety. This research is qualitative descriptive. The subject in this study is tenth grade of SMK Indomalay School Batam in Academic year 2015/2016. The totally number is 22 students. The data collected by Interview and questionnaire. The results showed that the factor causing of the students' speaking anxiety to speak in the language classroom are: lack of familiarity of task, fear of making mistakes, low motivation, incomprehensible inputs, lack of confidence and then low English proficiency. And the student's strategies to overcome speaking anxiety were peer seeking, preparation, relaxation, positive thinking and resignation.
\end{abstract}

Keywords: students' anxiety, speaking

\section{INTRODUCTION}

Speaking is the way to use language to communicate each other. By speaking, people around the world deliveries information and let the other people to know what the speaker talks about, it means that speaking is common activities in daily life and to communicate through speaking that contain interaction between speaker and listener.

Speaking is the product of creative contraction of linguistic strings; the speaker makes choices of lexicon, the structure and discourse. Speaking in language needs words to develop to be sentence and needs structure in language and the information that speaker giver acceptable and understood by listener.

By speaking the students have opportunity to delivery what the students want to inform to the listener. Without willingness to speak English, the successful language learner 
will not be reached by the students, but some students especially from SMK Indomalay School were anxiety to speak English in classroom.

During teaching practice program, the researcher found that students were afraid of delivering the student's ideas and also base on the teacher information about anxiety in speaking. The students of SMK Indomalay School Batam considered speaking as difficult skill to learn. Students did not willingness to speaking English in front of the class.

The students' problem in learning English were; there were many students lack of vocabularies, some of the students seldom to practice in speaking and some of the students were difficulty in pronunciation. The students need a confidence to speak in front of the class, but some of students had an anxiety when speak in classroom.

Based on Liu (2006:23), there are some causes of reticence (Anxiety to speak English), they are:

\section{a. Low English proficiency}

Low English proficiency is also identified in the present research as a major factor that hindered the students from talking to others in English in class. Thus, students may feel weak in speaking English, perceived their English to be poor, and may feel that the others is better than him or her.

\section{b. Lack of familiarity of task}

The word familiar means well known, often seen or heard, having a good knowledge, close or friendly to something. Interest mattered a lot in students active participation in classroom activities. In short, students will active in speaking about a topic if she or he is interest, well known, often see or heard, having a good knowledge or even close or friendly to a topic.

\section{c. Lack of confidence}

Confidence means having strong beliefs, firm trust, or sure expectation, feeling certain, fully assure, having no failure, etc. Some students might good have pronunciation and be at a high proficiency level but they still preferred to be reticent because of the lack of courage. 


\section{d. Fear of making mistakes}

The students worried about losing face in oral language classroom. Students keep quiet and wait until they were required to speak English, it was because the students were afraid and feel embarrassment of making mistakes.

\section{e. Incomprehensible inputs}

Language input comes in the form of teacher talk, listening activities, reading passages, and the language heard and read outside of class. It gives learners the material they need to begin producing language themselves.

There are five main categories of strategies as follow below:

\section{Preparation}

The students have use strategy to increase students' subjectively estimated mastery of the subject matter, and hence reduce the students' speaking anxiety in the classroom even in front of the teacher and other students.

\section{Relaxation}

Involves tactic that aim at reducing somatic anxiety symptoms of the students, with relaxation the students feel more calm done when anxiety appear.

\section{Positive thinking}

The students also have to use this strategy because this strategy is intended to divert attention from the stressful situation to positive and pleasant cues, and bring relief to the students' anxiety in speaking.

\section{Peer seeking}

Peer seeking is distinguished by students' willingness to look for other students who seem to have trouble understanding the class and controlling students' anxiety. For the students' anxiety, the realization that others are having the same problem may serve as a source of emotional regulation by social comparison. 


\section{Resignation}

This category is characterized by students' reluctance to do anything to alleviate the students speaking anxiety. The students reporting examples of resignation seem intent on minimizing the impact of anxiety by refusing to face the problem.

Johnston (2006:6) states some of the people get so anxious about making a mistake that the people's anxiety get out of control when speaking or performing in public. It means that actually people can solve anxiety by themselves.

According to Arikunto (2010:268) states mostly some of researcher did research by questionnaire to collect the data. The researcher gets information to reach researcher's aim by give the questionnaire to the students. Questionnaire is a collection of questions of the research to respondents to be answered. The characteristic of questionnaire is collecting data through list of written questions that are arranged and distributed to get information or explanation from score of data.

Moreover, Sugiyono (2014: 145) states that questionnaire is collecting data with efficient if researchers know for certain variables to be measured and know what is expected by.

Then, Riduwan (2012:20) states that a Likert scale is ask participants to respond a series of statement, namely strong agree (SA), agree (A), undecided (U), disagree (D), or strongly disagree (SD) with each statement. Indonesian language, strongly agree or sangatsetuju (SS), agree or setuju (S), undecided or ragu-ragu (RR), disagree or tidaksetuju (TS) and strongly disagree or sangat tidaksetuju (STS). The items of questionnaire used indonesian language to help the respondents to comprehend the items.

\section{METHODOLOGY}

The method of this research is descriptive qualitative research. The descriptive research involved collecting data in order to answer the question concerning with the status of the subject of the study.Qualitative research is the study intends to understand the phenomenon of what is experienced by the subject of the research. Such as motivation, perception, behavior, etc, in a holistic manner. The description is in the form of words and language, in a specific context naturally and by utilizing a variety of natural methods. 
Dealing with the theory, this research concerned with factors causing students`anxiety to speak English in language classroom.

\section{RESULTS}

The researcher gave questionnaire to 22 students, there were 5 (five) indicators with 10 items to known the factor causing of the students' speaking anxiety. Then, the researcher did interview there were 5 indicators with 10 questions to known the strategies of the students to overcome speaking anxiety. The interview between the researcher and students was done individually and pair. When did interview, the researcher used certain an interview guide, but in unstructured question.

Based on the data that collected by questionnaire, the researcher stated that the factor causing the anxiety at tenth grade of SMK Indomalay School Batam as below;

1. Lack of familiarity with task

2. Fear of making mistake

3. Low motivation

4. Incomprehensible input'

5. Lack of confidence

6. Low English proficiency

The most influencing factor causing of students' speaking anxiety was lack of familiarity with task, it shown by there were $86 \%$ of $100 \%$ students who answered strongly agree for each indicator, the second was fear of making mistake $84 \%$ of $100 \%$ students who strongly agree, the third was Low motivation $82 \%$ of $100 \%$ students who answered strongly agree, next was incomprehensible input $77 \%$ of $100 \%$ students who answered strongly agree, then lack of confidence $66 \%$ of $100 \%$ students who answered strongly agree, the last low English proficiency $59 \%$ of $100 \%$ students who answered strongly agree.

By the data that collected by interview with 22 students as on above table, the students' strategies to overcome speaking anxiety after sorted from the highest to lowest mean score as below:

1. Peer seeking

2. Preparation 


\section{Relaxation \\ 4. Positive thinking \\ 5. Resignation}

The highest strategy that the students did to overcome speaking anxiety was peer seeking, all of the students stated that peer seeking was the best strategy to overcome speaking anxiety in classroom. The first factor causing of speaking anxiety among the students was peer seeking with mean score of two question of peer seeking was $100 \%$. The second followed by preparation strategy, prepared material before started the lesson was a good strategy to ignore speaking anxiety, there were $98 \%$ of $100 \%$ students who answered yes for this items.The third was relaxation, there were $98 \%$ of $100 \%$ students also who stated that more relax can made the students were not anxiety to speak. Most students used relaxation strategy to overcome their speaking anxiety.Next, positive thinking was the next strategy to overcome speaking anxiety. There were $68 \%$ of $100 \%$ students who stated that positive thinking was a strategy to overcome speaking anxiety in the classroom. The last was resignation strategy that there were 10 students or $23 \%$ of $100 \%$ students who stated that resignation was a good strategy to overcome speaking anxiety. There were $77 \%$ students who answered that resignation was not a strategy to overcome the students' speaking anxiety.

\section{DISCUSSION}

The researcher concluded that there were many causes of students`anxiety to speak English in the classroom. Students were anxiety to speak English in class were caused by: lack of familiarity of task, fear of making mistakes, low motivation, incomprehensible inputs, lack of confidence and then low English proficiency. It was collected from the result of questionnaire did on $12^{\text {th }}$ May 2016 between the researcher and students of tenth grade of SMK Indomalay School Batam in Academic Year 2015/2016.

The researcher did the interview on $16^{\text {th }}$ May 2016 at tenth grade of SMK Indomalay School Batam to know the students' strategies to overcome speaking anxiety.The student's strategies to overcome speaking anxiety were peer seeking, preparation, relaxation, positive thinking and resignation. The researcher concluded the highest strategies that the students did to overcome speaking anxiety was peer seeking, all of the students stated that peer seeking was the best strategy to overcome speaking anxiety in classroom. There were $100 \%$ the students answered yes for this strategy. 
Based on the result of this study, dominantly students`anxiety to speak English was caused by lack of confidence. Therefore, the researcher would like to give some suggestion to the English teacher, especially in teaching process. The teacher is expected to pay attention to those factors that causing students anxiety to speak English in language classroom. Therefore, the teacher is expected to support and encourage students to speak English in the classroom.

From the result of this research, the researcher would like to give suggestionto the students who are anxiety to speak English in classroom. The students are expected to increase the students' self-confidence to speak, the students are expected to increase the students' English proficiency in speaking English.

Based on the result of this research, the researcher would like to give a suggestion to the other researcher. Others researchers are expected to use this research to add their knowledge about anxiety to speak English. Besides, they are expected to do other research that related to students`speaking English in language classroom.

\section{REFERENCES}

Arikunto, Suharsimi.(2010). Prosedur penelitian. Jakarta: PT. RinekaCipta.

Johnston, Joni. (2006). Controling anxiety. United Stated America: Penguin group.

Liu, Meihua. (2006). Anxiety in EFL classrooms: Causes and consequences. China: Tsinghua University.

Riduwan, M.B.A. (2012). Statistika. Bandung: Alfabeta.

Sugiyono.(2014).Metode penelitian kuantitatif kualitatif. Indonesia: Alfabeta. 